\title{
Front Matter: Volume 7116
}

, "Front Matter: Volume 7116," Proc. SPIE 7116, Optically Based Biological and Chemical Detection for Defence IV, 711601 (30 October 2008); doi: $10.1117 / 12.817093$

SPIE. Event: SPIE Security + Defence, 2008, Cardiff, Wales, United Kingdom 


\section{PROCEEDINGS OF SPIE}

\section{Optically Based Biological and Chemical Defection for Defence IV}

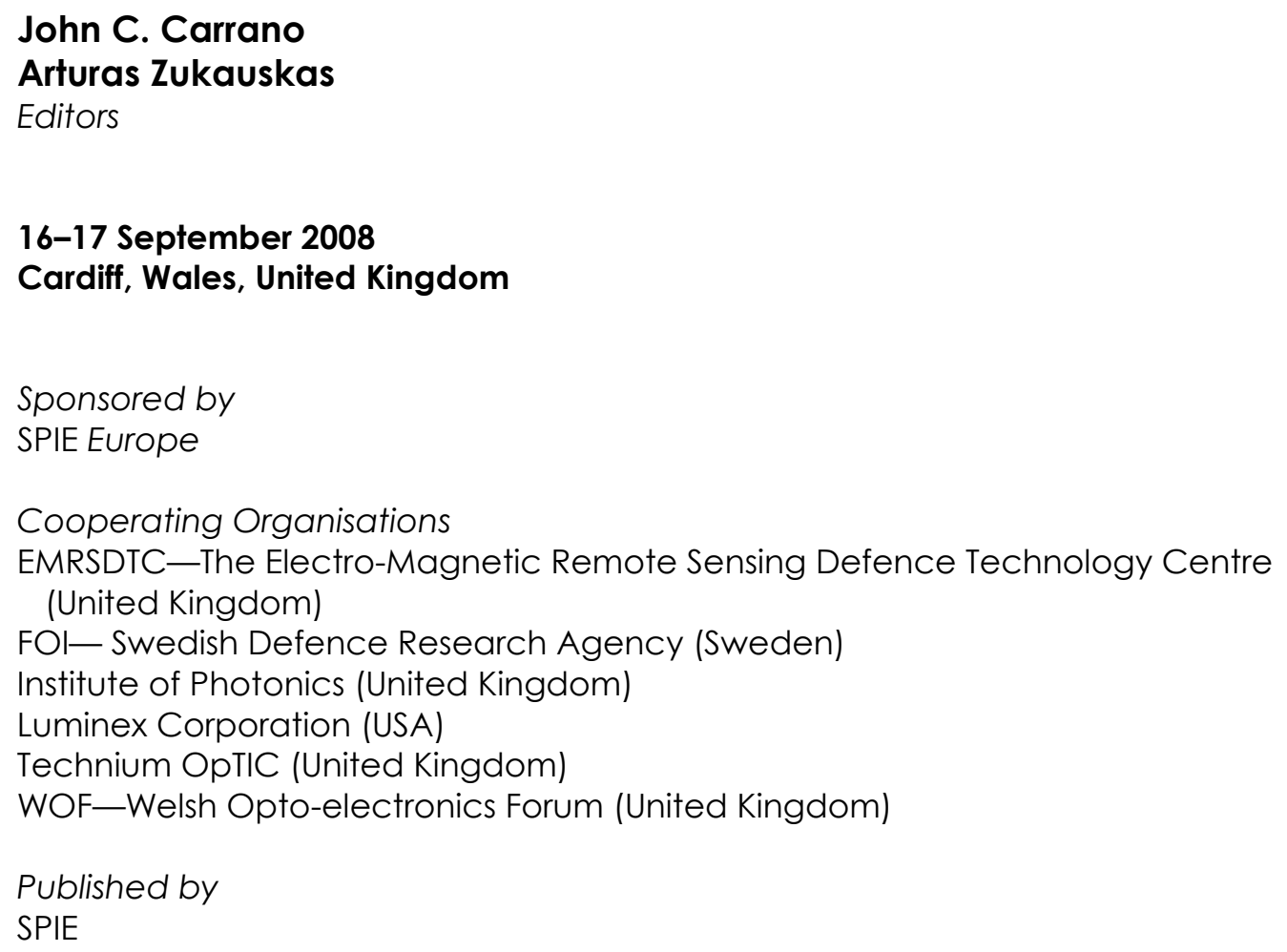


The papers included in this volume were part of the technical conference cited on the cover and title page. Papers were selected and subject to review by the editors and conference program committee. Some conference presentations may not be available for publication. The papers published in these proceedings reflect the work and thoughts of the authors and are published herein as submitted. The publisher is not responsible for the validity of the information or for any outcomes resulting from reliance thereon.

Please use the following format to cite material from this book:

Author(s), "Title of Paper," in Optically Based Biological and Chemical Detection for Defence IV, edited by John C. Carrano, Arturas Zukauskas, Proceedings of SPIE Vol. 7116 (SPIE, Bellingham, WA, 2008) Article CID Number.

ISSN 0277-786X

ISBN 9780819473486

Published by

SPIE

P.O. Box 10, Bellingham, Washington 98227-0010 USA

Telephone +1 3606763290 (Pacific Time) · Fax +1 3606471445

SPIE.org

Copyright (C) 2008, Society of Photo-Optical Instrumentation Engineers

Copying of material in this book for internal or personal use, or for the internal or personal use of specific clients, beyond the fair use provisions granted by the U.S. Copyright Law is authorized by SPIE subject to payment of copying fees. The Transactional Reporting Service base fee for this volume is $\$ 18.00$ per article (or portion thereof), which should be paid directly to the Copyright Clearance Center (CCC), 222 Rosewood Drive, Danvers, MA 01923. Payment may also be made electronically through CCC Online at copyright.com. Other copying for republication, resale, advertising or promotion, or any form of systematic or multiple reproduction of any material in this book is prohibited except with permission in writing from the publisher. The CCC fee code is $0277-786 \times / 08 / \$ 18.00$.

Printed in the United States of America.

Publication of record for individual papers is online in the SPIE Digital Library.

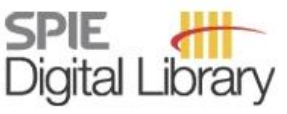

SPIEDigitalLibrary.org

Paper Numbering: Proceedings of SPIE follow an e-First publication model, with papers published first online and then in print and on CD-ROM. Papers are published as they are submitted and meet publication criteria. A unique, consistent, permanent citation identifier (CID) number is assigned to each article at the time of the first publication. Utilization of CIDs allows articles to be fully citable as soon they are published online, and connects the same identifier to all online, print, and electronic versions of the publication. SPIE uses a six-digit CID article numbering system in which:

- The first four digits correspond to the SPIE volume number.

- The last two digits indicate publication order within the volume using a Base 36 numbering system employing both numerals and letters. These two-number sets start with 00, 01, 02, 03, 04, 05 , $06,07,08,09,0 A, O B \ldots$. OZ, followed by 10-1Z, 20-2Z, etc.

The CID number appears on each page of the manuscript. The complete citation is used on the first page, and an abbreviated version on subsequent pages. Numbers in the index correspond to the last two digits of the six-digit CID number. 


\section{Contents}

$\checkmark \quad$ Conference Committee

IDENTIFIERS AND DIAGNOSTICS

711603 Novel optical sensors for detection of toxins, viruses, and bacteria [7116-03]

G. D. Emmerson, I. J. G. Sparrow, D. Bhatta, J. E. SohnaSohna, Stratophase Ltd. (United Kingdom)

711605 Low cost LED-based xMAP analyzer for multiplexed diagnosis and environmental detection of biological agents [71 16-05]

C. J. Collins, A. Altman, W. Roth, J. C. Carrano, Luminex Corp. (United States)

\section{CHEMICAL AND EXPLOSIVE DETECTION}

711609 A gas micromechanical sensor based on surface plasmons resonance [7116-09] J. Hastanin, Y. Renotte, Univ. de Liège (Belgium); K. Fleury-Frenette, J. M. Defise, Ctr. Spatial de Liège (Belgium); S. Habraken, Univ. de Liège (Belgium) and Ctr. Spatial de Liège (Belgium)

\section{ASSAYS AND SIGNATURES}

$71160 \mathrm{C}$ Improved laser-induced fluorescence method for bio-attack early warning detection system [7116-12]

G. Feugnet, E. Lallier, A. Grisard, Thales Research \& Technology (France); L. McIntosh, J. E. Hellström, Cobolt AB (Sweden); P. Jelger, F. Laurell, Kungliga Tekniska Högskolan (Sweden); C. Albano, Umetrics AB (Sweden); M. Kaliszewski, M. Wlodarski, J. Mlynczak, M. Kwasny, Z. Zawadzki, Z. Mierczyk, K. Kopczynski, Wojskowa Akademia Techniczna (Poland); A. Rostedt, M. Putkiranta, M. Marjamäki, J. Keskinen, Tampere Univ. of Technology (Finland); J. Enroth, K. Janka, R. Reinivaara, L. Holma, Dekati Ltd. (Finland); T. Humppi, The Finnish Defence Forces (Finland); E. Battistelli, Galileo Avionica S.p.A. (Italy); E. lliakis, G. Gerolimos, Teletel S.A. (Greece)

\section{BIO-AEROSOL DETECTION I}

7116 OD Overview of the TAC-BIO detector (Invited Paper) [7116-13] J. Cabalo, M. DeLucia, A. Goad, J. Lacis, F. Narayanan, D. Sickenberger, U.S. Army Edgewood Chemical Biological Center (United States)

7116 OF Single aerosol particle selection and capture using laser scattering and fluorescence [7116-16]

J. D. Eversole, V. Sivaprakasam, Naval Research Lab. (United States); T. A. Pletcher,

D. Keller, Sarnoff Corp. (United States) 
711606 The optical detection system of FABIOLA [7116-17]

E. Battistelli, R. Paolinetti, C. Pompei, S. Puccini, Galileo Avionica S.p.A. (Italy)

BIO-AEROSOL DETECTION II

$711601 \quad$ Low-cost real-time multiparameter bio-aerosol sensors (Invited Paper) [7116-19]

V. E. Foot, Defence Science and Technology Lab. (United Kingdom); P. H. Kaye,

W. R. Stanley, Univ. of Hertfordshire (United Kingdom); S. J. Barrington, Defence Science and Technology Lab. (United Kingdom); M. Gallagher, A. Gabey, The Univ. of Manchester (United Kingdom)

$71160 \mathrm{~J}$ Dual-wavelength-excitation single-particle fluorescence spectrometer/particle sorter for real-time measurement of organic carbon and biological aerosols (Invited Paper) [7116-20]

Y.-L. Pan, Yale Univ. (United States); R. G. Pinnick, S. C. Hill, Army Research Lab. (United

States); H. Huang, R. K. Chang, Yale Univ. (United States)

\section{DEVICES AND SPECTROSCOPY}

$71160 \mathrm{~N}$ A reagentless real-time method for the multiparameter analysis of nanoparticles as a potential 'trigger' device [7116-24]

B. Carr, J. Knowles, J. Warren, NanoSight Ltd. (United Kingdom)

711600 Advanced double-pulse UV source for laser-induced fluorescence of bio-aerosols [7116-25]

G. Feugnet, A. Grisard, E. Lallier, Thales Research \& Technology (France); L. Mclntosh,

J. Hellström, Cobolt AB (Sweden)

\section{CHEMICAL AND EXPLOSIVE DETECTION III}

$71160 Q$ Database for chemical weapons detection: first results [7116-28]

C. Bellecci, P. Gaudio, M. Gelfusa, S. Martellucci, M. Richetta, P. Ventura, A. Antonucci, Univ. of Rome Tor Vergata (Italy); F. Pasquino, V. Ricci, A. Sassolini, NBC Joint Logistic Technical Ctr. (Italy)

$7116 \mathrm{OR}$ Cumulative sum and neural network approach to the detection and identification of hazardous chemical agents from ion mobility spectra [7116-29]

M. Ruotsalainen, J. Vihonen, J. Jylhä, J. Kauppila, Tampere Univ. of Technology (Finland);

O. Anttalainen, Environics Oy (Finland); A. Visa, Tampere Univ. of Technology (Finland)

7116 OS Remote detection of liquids by Raman line imaging [7116-15]

C. R. Howle, C. D. Dyer, Defence Science and Technology Lab. (United Kingdom);

K. J. Baldwin, R. J. White, Avacta Ltd. (United Kingdom)

7116 OT Detection of explosive related nitroaromatic compounds (ERNC) by laser-based ion mobility spectrometry [7116-31]

R. Laudien, Optimare GmbH (Germany); D. Riebe, T. Beitz, H.-G. Löhmannsröben,

Univ. Potsdam (Germany) 


\title{
Conference Committee
}

\author{
Symposium Chair \\ David H. Titterton, Defence Science and Technology Laboratory \\ (United Kingdom) \\ Conference Chairs \\ John C. Carrano, Luminex Corporation (United States) \\ Arturas Zukauskas, Vilnius University (Lithuania)
}

Program Committee

Charles J. Collins, Luminex Corporation (United States)

David W. Cullin, ICx Technologies, Inc. (United States)

Richard K. DeFreez, ICx Mesosystems (United States)

Sherry A. Dunbar, Luminex Corporation (United States)

Virginia E. Foot, Defence Science and Technology Laboratory (United Kingdom)

William F. Hug, Photon Systems, Inc. (United States)

Thomas H. Jeys, MIT Lincoln Laboratory (United States)

Mikael Lindgren, Norwegian University of Science and Technology (Norway)

Chandra K. Patel, Pranalytica, Inc. (United States)

David W. Sickenberger, U.S. Army Research, Development and Engineering Command (United States)

Ngai M. Wong, Defense Threat Reduction Agency (United States)

\section{Session Chairs}

1 Keynote Session

John C. Carrano, Luminex Corporation (United States)

2 Identifiers and Diagnostics

John C. Carrano, Luminex Corporation (United States)

3 Chemical and Explosive Detection

Dean P. Neikirk, The University of Texas at Austin (United States)

$4 \quad$ Assays and Signatures

Amy L. Altman, Luminex Corporation (United States)

5 Bio-Aerosol Detection I

Thomas H. Jeys, MIT Lincoln Laboratory (United States) 
6 Bio-Aerosol Detection II

Charles J. Collins, Luminex Corporation (United States)

7 Devices and Spectroscopy

Chandra-Kumar N. Patel, Pranalytica, Inc. (United States)

8 Chemical and Explosive Detection III

Charles J. Collins, Luminex Corporation (United States) 